\title{
PHYTOACCUMULATION OF CHROMIUM(VI) METAL ION BY SNAKE PLANT (Sansevieria tifasciata Prain)
}

\author{
Nini Astuti Alwi ${ }^{1,2^{*}}$, Asmawati ${ }^{1,2}$, Syarifuddin Liong ${ }^{1,2}$ \\ ${ }^{1}$ Analytical Laboratory, Department of Chemistry, Faculty of Mathematics and Natural Sciences, \\ Hasanuddin University \\ ${ }^{2}$ Department of Chemistry, Faculty of Mathematics and Natural Sciences, Hasanuddin University, \\ Perintis Kemerdekaan Street KM 10, Tamalanrea Makasssar, Indonesia 90245 \\ *Corresponding author: nn5794aa.nhya94@gmail.com
}

\begin{abstract}
Abstrak. Tanaman lidah mertua (Sansevieria trifasciata Prain) digunakan sebagai salah satu teknik fitoremediasi untuk menyerap logam krom. Tanaman lidah mertua untuk mengakumulasi ion logam $\mathrm{Cr}(\mathrm{VI})$ dari tanah dengan menggunakan variasi konsentrasi pencemar dan variasi waktu. Konsentrasi pencemar yang digunakan adalah 100; 200; 400; dan 800 ppm. Konsentrasi ion logam Cr dapat diukur dengan menggunakan Spektrofotometer Serapan Atom (SSA). Hasil penelitian menunjukkan bahwa akumulasi ion logam $\mathrm{Cr}(\mathrm{VI})$ pada lidah mertua paling besar pada pekan ketiga yaitu $6,30 \mathrm{mg} / \mathrm{kg}$ berat kering. Jenis mekanisme fitoremediasi yang terjadi pada akumulasi logam $\mathrm{Cr}(\mathrm{VI})$ pada lidah mertua adalah rhizofiltrasi. Berdasarkan hasil tersebut tanaman lidah mertua tidak berpotensi sebagai tanaman hiperakumulator terhadap logam krom.
\end{abstract}

Kata Kunci: Fitoremediasi, Hiperakumulator, Lidah Mertua, Kromium.

Abstract. Snake plant (Sansevieria trifasciata Prain) used as one of the phytoremediation techniques to absorb chromium metal. Snake plants (Sansevieria trifasciata Prain) to accumulate ion of $\mathrm{Cr}(\mathrm{VI})$ from the soil by using variation of pollutant concentration and time variation. Pollutant concentration used were 100; 200; 400; and 800ppm. The concentration of metal ions $\mathrm{Cr}(\mathrm{VI})$ that has been absorbed can be determined using Atomic Absorption Spectrophotometer (AAS). The result showed that the accumulation of metal ions $\mathrm{Cr}(\mathrm{VI})$ on snake plant biggest in the third week which is $6,30 \mathrm{mg} / \mathrm{kg}$ dry weight. Types or phytoremediation mechanisms that occur in the accumulation of $\mathrm{Cr}(\mathrm{VI})$ in snake plant is rhyzofiltration. Based on the result of snake plant are not potentially as hyperaccumulator plant of Chrom.

Keywords: Phytoremediation, Hyperaccumulator, Sansevieria tifasciata Prain., Crhomium. 


\section{INTRODUCTION}

One of the main environmental problems is heavy metal contamination. Heavy metals continue to increase due to the continuous use of heavy metals in various industrial and household fields. Heavy metal contamination causes stress on plants that can demage soil fertility so that cropped production decreases (Jeliazko, 2001; Hardiani, 2009).

Some heavy metals that have the potential to pollute the enviroment are lead $(\mathrm{Pb})$, arsenic $(\mathrm{As})$, chrome $(\mathrm{Cr})$, nickel $(\mathrm{Ni})$, cadmium $(\mathrm{Cd})$, copper $(\mathrm{Cu})$, zink $(\mathrm{Zn})$, selenium $(\mathrm{Se})$, dan mercury $(\mathrm{Hg})$ (Chaney, et. al., 1997; Fardiaz, 2008).

According to Machbub dan Mulyadi (2000), the most dominant heavy metals pollute the environment which has exceeded the threshold according to PP no. 82 of 2001 is chrome. Chrome is a heavy metal that essential at low levels and carcinogenic in high quantities (Candra et. al., 2007; ATSDR, 2006).

One alternative and enviromentally friendly method to reduce heavy metal contamination in the enviroment is the phytoremediation method. According to Aiyen (2004) Phytoremediation is a method that immobilizes metals that become contaminants in the soil using plant. The plant is known as a hyperaccumulator plant.

Hyperaccumulator plants are plant that are capable of translating pollutant metal to parts of the plant more than the roots. Some plants have a high ability to accumulate various existing pollutans. The limitation of phytoremediation technique is limitation concentration of contaminants that can be tolerated by plants. Hyperaccumulator plants can accumulate more than $10 \mathrm{ppm}(\mathrm{Hg}), 100 \mathrm{ppm}(\mathrm{Cd})$, $1000 \mathrm{ppm}(\mathrm{Co}, \mathrm{Cr}, \mathrm{Cu})$, and $10.000 \mathrm{ppm}$ (Ni and Zn) (Aiyen, 2004; Subroto, 1996).

Hyperaccumulator plants against $\mathrm{Cr}$ metal have been found by several researchers such as Muliadi, et. Al (2013) examined the phytoremediation of $\mathrm{Cr}$ metal using land water spinach (Ipomea reptana) with a concentration of 133.115 $\mathrm{mg} / \mathrm{kg}$; according to Hartanti et. al., (2014) water hyacinth plants (Eichornia crassipes) found as much as $2.23 \mathrm{mg} / \mathrm{L}$ of chrome metal; Putri et. al (2014) plants with several species of Eichornia crassipes solm water hyacinth, Heteranthera peduncularis and Monochoria vaginalis have concentrations of $\mathrm{Cr}$ accumulation of $1.5395 \mathrm{Cr}$; 0.5728; and $0.1057 \mu \mathrm{g} / \mathrm{gr}$. The results of these studies indicate that at certain concentrations of metal $\mathrm{Cr}$ affects plant growth.

Snake plants (Sansevieria trifasciata Prain) is one of species of Sansevieria plants, including pollution-absorbing plants that are quite effective (Pradipta, 2011). This plant can grow under conditions of little water and sunlight so it is suitable with the tropical climate and has a high adaptability to the environment (Purwanto, 2006). Lidah mertua is able to accumulate heavy metals because these plants contain steroidal saponin compounds, sulfuhidril groups $(-\mathrm{SH})$ and carboxyl groups (-COOH) (Mimaki et. al., 1996; Yusuf et. al., 2015).

Problems regarding heavy metal pollution and the existence of highly supportive phytoremediation techniques, it is necessasary to develop research on the types of plants capable of accumulating heavy metals. The plant used in this study for remediation of $\mathrm{Cr}$ metal on the ground 
was the lidah mertua (Sansiveria trifasciata Prain).

\section{MATERIAL AND METHODS Materials}

The materials used in this study were $\mathrm{K}_{2} \mathrm{Cr}_{2} \mathrm{O}_{7}$, soil, seed of Snake plants (Sansevieria trifasciata Prain), $\mathrm{H}_{2} \mathrm{O}_{2} 30 \%$, $\mathrm{HNO}_{3}(6 \mathrm{M})$, aquades, aquabides, universal $\mathrm{pH}$ paper, and Whatman No. 42 filter paper.

\section{Tools}

The tools used in this study are basin, flower pot, analytic blancr, oven, desiccator, hot plate, petridish, mortar, horn spoon, artificial waste making equipment, glassware, and Atomic Absorption Spectrophotometer (AAS), Back Scientific 205 VGP model.

\section{The Procedures}

\section{Soil Media Preparation}

The soil that used in this study was taken from vegetable plantations. The soil is cleared of rocks and roots. Content of nitrogen, phosphate, potassium, chrome (Cr), Cation Exchange Capacity (CEC) and organic matter in the soil were analyzed at the soil science laboratory. The soil is then stirred and aerated for two weeks left.

\section{Contaminated Cr(VI) Production}

Soil that has been prepared through the drying and stirring stage, added a solution of $\mathrm{Cr}(\mathrm{VI})$ as a pollutant at various concentration, there is $100,200,400$, and 800ppm.

\section{Preparation of Plant Media}

Some clean pots are filled with $1.5 \mathrm{~kg}$ of soil mixed with $\mathrm{Cr}(\mathrm{VI})$. The soil is then sprinkled with TSP fertilizer and $\mathrm{KCl}$, then doused with distilled water. Control is done with the same size pot and the same amount of soil but the soil used doesn't contaoin the ions.

\section{Planting Snake Plant}

Snake plant that age \pm 1 month planted in pots that have been provided. Every day, the plants are doused with distilled water. Harvesting is done every week for four weeks. Harvested Snake plant are washed with free mineral water so that they are clean of soil and other objects. Cleanly separated roots and limbs are then stored in a plastic bag and ready to be chemically analyzed.

\section{Analysis of $\mathrm{Cr}$ (VI) Levels on Leaves and Legs}

Methods of analyzing $\mathrm{Cr}$ (VI) refers to procedures that have been used by Hummer (2002), Pioterowesk-Cyplik and Csamekai (2005), Nouairi et. al. (2005), Aiyen (2004), and Cave et. al. (2000). Generally, the researchers said that analysis of metal ions contained in organic matter, the wet method is better to use than the dry method.

Clean roots and limbs are aerated for several hours. Than, it was carefully weighed on the petridish who had known their empty weight. Part of the plants is heated in the oven for 24 hours at $80{ }^{\circ} \mathrm{C}$, then cooled in a desiccator. The dried part of the plant is weighed back so that the weight lost is known as the amount of water contained in the roots and leaves.

This dry sample is then crushed on porcelain mortar. The crushed sample is weighed approximately $0.5 \mathrm{~g}$ with an analytical balance. The example was 
dissolved with $5 \mathrm{~mL}$ of $6 \mathrm{M} \mathrm{HNO}_{3}$ and 5 $\mathrm{mL}$ of $30 \% \mathrm{H}_{2} \mathrm{O}_{2}$, heated until all the material dissolved completely. The solution is cooled, added aquabides, heated and filtered in hot conditions into a $50 \mathrm{~mL}$ volumetric flask. This sample solution is regulated by $\mathrm{pH}$ using $\mathrm{HNO}_{3}$ and $\mathrm{NaOH}$ until the $\mathrm{pH}$ is around 2-3. The solution is crushed to the limit with aquabides $\mathrm{pH} 2$ and shaken until homogeneous. The solution is ready to be measured by Atomic Absorption Spectrophotometry (AAS).

\section{Determination of Optimum Accumulation Cr (VI)}

In determining the optimum time for absorption of Cr (VI) by the Snake plant, harvest is carried out after the plant is one week old. Subsequent harvests are carried out every week for 4 weeks. Each time the harvest, the Snake plant is cleared from the soil and other impurities, then the roots and limbs are separated and analyzed like procedure $\mathrm{E}$. The optimum time is the time when the maximum absorption of $\mathrm{Cr}$ (VI) can be obtained from the curve versus the absorption time.

\section{Effect of Concentration on the Amount of Ions Accumulated in the Snake Plant}

Determination of the concentration $\mathrm{Cr}$ (VI) on growing media in the number of ions accumulated in plants with variations the concentration of $\mathrm{Cr}$ (VI) ions are 100; 200; 400; and 800ppm. Then these contaminated soils are planted with Snake plant according to procedure D. Harvesting is done at week 3 according to the optimum time obtained in procedure F. Furthermore, the content of $\mathrm{Cr}$ (VI) in the roots and limbs of Snake plant is analyzed according to the procedure E.

\section{Mechanism of Accumulation Cr (VI) on Snake Plants}

Determination of the mechanism of heavy metal accumulation in plants is carried out according to the procedure of Gosh Singh (2005) by calculating the bioconcentration factor (BCF) and translocation factor (TF) with the following formula:

\section{Bioconcentration Factor $\mathrm{BCF}=\frac{[\mathrm{M}] \text { pada bagian akar tanaman }(\mathrm{mg} / \mathrm{kg} \mathrm{BK})}{[\mathrm{M}] \text { yang ditambahka } \mathrm{n} \text { ke dalam tanah }(\mathrm{mg} / \mathrm{kg} \mathrm{BK})}$ $\mathrm{TF}=\frac{[\mathrm{M}] \text { dalam daun }(\mathrm{mg} / \mathrm{kg} \mathrm{BK})}{[\mathrm{M}] \text { dalam akar }(\mathrm{mg} / \mathrm{kg} \mathrm{BK})}$}

\section{RESULTS AND DISCUSSION Introduction Analysis}

The nature of the soil is very important to know so that preliminary analysis is carried out to determine the concentration of $\mathrm{Cr}$ (VI) in soil and fertilizers before being used as a medium for planting Snake plant. Table 1. shows the $\mathrm{Cr}$ metal content of soil and fertilizer.

Table 1. Cr Metal Content in Soil and Fertilizers

\begin{tabular}{lc}
\hline \multicolumn{1}{c}{ Sample } & [Cr] $\mathbf{~ m g / k g}$ \\
\hline Soil & 2,94 \\
Compost & 20,23 \\
$\mathrm{CaCO}_{3}$ Fertilizers & - \\
\hline
\end{tabular}

The results of the analysis showed that soil and compost contained $\mathrm{Cr}$, respectively 2.94 and $20.33 \mathrm{mg} / \mathrm{kg}$. In addition to analysis of $\mathrm{Cr}$ content, physical and chemical analysis of soil was carried 
out to determine the level of soil fertility and soil type (Table 2). Some parameters used include soil texture, water content, organic matter content (C), cation exchange capacity and levels of N, P, K. The results of the analysis show that the soil is soil with a texture consistent with the growth of Snake plants. The soil includes the type of sandy clay, otherwise known as alluvial soil. Soil texture is very important for determining soil characteristics, water, stored, pore size and development of plant roots because it affects the speed of water withdrawal, aeration and soil fertility. While the soil $\mathrm{pH}$ used is around $\mathrm{pH} 5.5$ 8.5 which is a good condition for the growth and development of the Snake plants.

Cation exchange capacity (CEC) is the ability to absorb cations (heavy metals) and the ability to exchange cations between cations present in the soil and solution. The capacity of cation exchangers in the soil used was $19.5 \mathrm{cmol} / \mathrm{kg}$ which is a moderate area according to 1986 FAO (17-24 $\mathrm{cmol} / \mathrm{kg}$ ). The content of organic matter affects soil mineral content, physical and chemical properties of soil. The content of organic matter in the soil used $\mathrm{C} 1.59 \%$ and N $0.11 \%$ which, according to FAO (1986) are included in the low category (1-1.9\%).

Table 2. Physical and Chemical Properties of Soil Used

\begin{tabular}{lc}
\hline \multicolumn{1}{c}{ Parameter Test } & Results \\
\hline Sand (\% dry weight) & 58,00 \\
\hline Dust $(\%$ dry weight) & 21,00 \\
\hline Clay $(\%$ dry weight $)$ & 21,00 \\
\hline Water content & 5,10 \\
\hline Cation exchange capacity $(\mathrm{cmol} / \mathrm{kg})$ & 19,58 \\
\hline Content of organic matter $(\% \mathrm{C})$ & 1,59 \\
\hline $\mathrm{N}(\%$ dry weight $)$ & 0,11 \\
\hline $\mathrm{P}(\%$ dry weight $)$ & 10,40 \\
\hline $\mathrm{K}(\mathrm{cmol} / \mathrm{kg})$ & 0,14 \\
\hline
\end{tabular}

The results of the analysis showed that the soil used in this study contained $\mathrm{Cr}$ heavy metals but did not have a negative effect on all vegetables grown at the site. The results of the analysis of the physical and chemical properties of the soil indicate that some test parameters are considered to be eligible for the planting of Lidah mertua, even though the nitrogen content is still low so fertilization with compost and $\mathrm{CaCO}_{3}$ fertilizers is carried out.

\section{Analysis of the Content of Cr (VI) After Accumulation}

\section{Effect of Harvest Time of Cr (VI) Ions}

The amount of $\mathrm{Cr}$ (VI) which accumulates on the Snake plant as a function of harvest time is shown in Figure 1. 


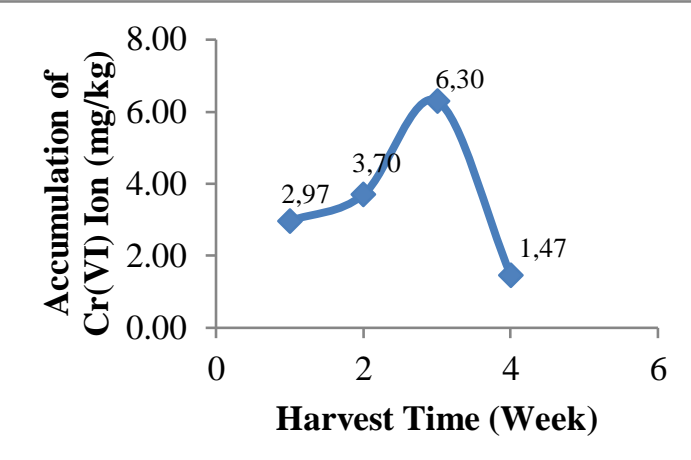

Figure 1. Effect of Harvest Time on the Amount of Cr (VI) Ions Accumulated in Snake plant.

The results of the analysis show that $\mathrm{Cr}$ (IV) ions accumulated by the Snake plant in the first week of the fourth week in a row are $2.97 ; 3.70 ; 6.30$; and $1.47 \mathrm{mg} / \mathrm{kg}$ (Figure 1) with maximum accumulation in the third week of $6.30 \mathrm{mg} / \mathrm{kg}$ dry weight. In the fourth week the accumulation of $\mathrm{Cr}$ (VI) decreased by $1.47 \mathrm{mg} / \mathrm{kg}$ because the roots in the plants were no longer able to absorb $\mathrm{Cr}$ metal ions on the soil (critical phase). In addition, the Snake plant has experienced physical abnormalities such as chlorosis (yellowing and pale leaves), and withering. This physical abnormality occurs due to nutrient absorption caused by $\mathrm{Cr}$ (VI). In general, homoestatic conditions in a living system can tolerate a certain amount of metal concentration without interfering with its growth. But large metal concentrations can reduce detoxification ability so that plants experience impaired absorption and growth.
2. Effect of Concentration on the Amount of $\mathrm{Cr}$ (VI) Ions

The amount of $\mathrm{Cr}$ (VI) ions accumulated in the Snake plant as a function of ion concentration added to soil media is shown in Figure 2. The accumulation of $\mathrm{Cr}$ (VI) in the concentration variations on the growing media shows that the ability of Snake plant accumulation increases with a concentration up to $400 \mathrm{ppm}$ and decreased at $800 \mathrm{ppm}$ with the accumulation of $\mathrm{Cr}$ (VI) in a row of $1.96 ; 2.14 ; 7.47$; and 4.21 $\mathrm{mg} / \mathrm{kg}$. Cr (VI) ion is a hard acid so this ion is difficult to interact with phytochelatin compounds that have $-\mathrm{SH}$ groups in the plant.

The highest number of $\mathrm{Cr}$ (VI) ions that can be accumulated by the Snake plant (7.47 $\mathrm{mg} / \mathrm{kg}$ dry weight) is obtained at the addition of $400 \mathrm{ppm}$ on the growing medium. 


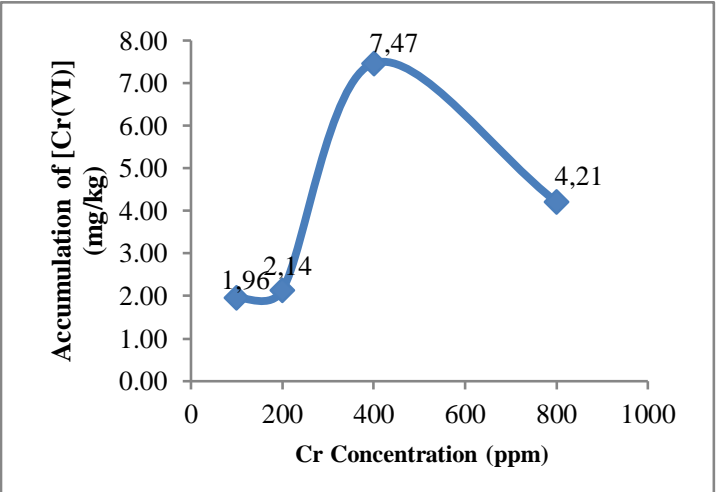

Figure 2. Effect of Concentration on the Amount of Ion-Ion Cr (VI) Accumulated in Snake Plants

3. Absorption Mechanism from Snake Plants

In general, all types of plants are accumulators against metals, but not all plants function as hyperaccumulators. A plant is called a hyperaccumulator of $\mathrm{Cr}$ metal if it is able to attract metals in a high enough concentration of 1000ppm (Lasat, 2000).

Snake plant is a type of hyperaccumulator because it contains a protein that has an amine group (-NH2), a carboxyl group $(-\mathrm{COOH})$, as well as a sulfidril group (-SH) which can bind heavy metals.

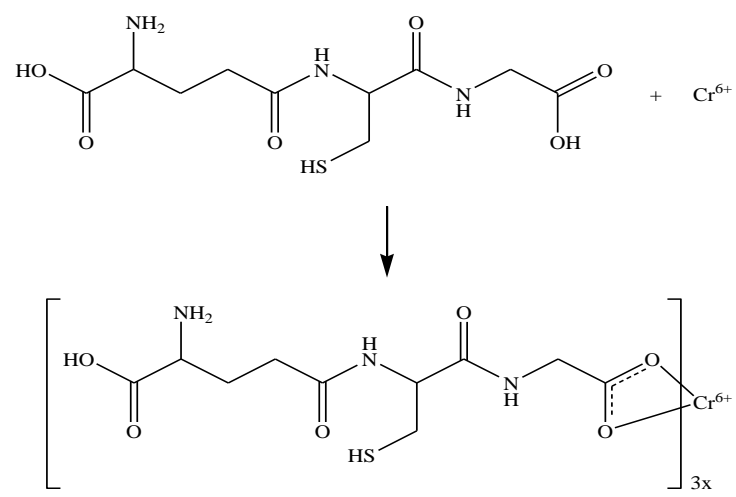

Figure 3. Metal Binding Mechanism in Plants

The results of analysis accumulation of $\mathrm{Cr}$ (VI) on soil media, give a value smaller than $1000 \mathrm{ppm}$ in soil contaminated with $100 \%$ of $\mathrm{Cr}$ (VI); 200; 400; 800 ppm, so that the Snake plant cannot be called a hyperaccumulator plant against chrome.

To determine the mechanism of accumulation of $\mathrm{Cr}$ (VI) by the Snake plants, it is necessary to calculate the value of bioconcentration (BCF) and translocation (TF) factors. The translacocation factor (FT) is closely related to the ability to accumulate and translocate metals from the soil to the top of plants. BCF and TF values as a function of Snake plant accumulation of Cr (VI) ions are shown in Table 3. 
Table 3. BCF and TF Value

\begin{tabular}{|c|c|c|c|}
\hline Time & Consentration of $\mathrm{Cr}$ Ion & $\begin{array}{c}\text { BCF } \\
\text { Value }\end{array}$ & $\begin{array}{c}\text { TF } \\
\text { Value }\end{array}$ \\
\hline \multirow{4}{*}{$\begin{array}{l}\text { First } \\
\text { Week }\end{array}$} & 100 & 0,00 & 0,98 \\
\hline & 200 & 0,00 & 0,91 \\
\hline & 400 & 0,02 & 0,05 \\
\hline & 800 & 0,00 & 2,20 \\
\hline \multirow{4}{*}{$\begin{array}{l}\text { Second } \\
\text { Week }\end{array}$} & 100 & 0,00 & 1,01 \\
\hline & 200 & 0,00 & 0,00 \\
\hline & 400 & 0,01 & 0,00 \\
\hline & 800 & 0,01 & 0,09 \\
\hline \multirow{4}{*}{$\begin{array}{l}\text { Third } \\
\text { Week }\end{array}$} & 100 & 0,00 & 0,00 \\
\hline & 200 & 0,00 & 4,40 \\
\hline & 400 & 0,02 & 0,00 \\
\hline & 800 & 0,01 & 0,00 \\
\hline \multirow{4}{*}{$\begin{array}{l}\text { Fourth } \\
\text { Week }\end{array}$} & 100 & 0,04 & 0,00 \\
\hline & 200 & 0,00 & 0,00 \\
\hline & 400 & 0,00 & 1,01 \\
\hline & 800 & 0,00 & 0,00 \\
\hline
\end{tabular}

According to Liong et al., (2010) $\mathrm{BCF}$ values are generally greater than one, while TF values are generally smaller than one. The BCF value is inversely proportional to the TF value indicating that the Snake plant has the ability to accumulate $\mathrm{Cr}$ (VI) ions, but the ability to translocate metals is still low (Yoon et al., 2006). The results of the analysis show that the mechanism that occurs in the accumulation of $\mathrm{Cr}$ on the Snake plant is Rhizofiltration.

\section{Distribution of $\operatorname{Cr}(\mathrm{VI})$ in Snake Plant}

Figures 3 and 4 show the distribution of $\mathrm{Cr}$ (VI) in the roots and leaves of the Snake plant leaves on variations in harvest time and the concentration of $\mathrm{Cr}(\mathrm{VI})$ ions in the growing media. These two images show that in general the concentration of $\mathrm{Cr}$ (VI) ions is higher in the roots than in the upper part of the plant. Roots are parts of plants in the soil that interact directly with $\mathrm{Cr}$ (VI) ions through rizofer which will form complexes with chelating compounds (organic acids).

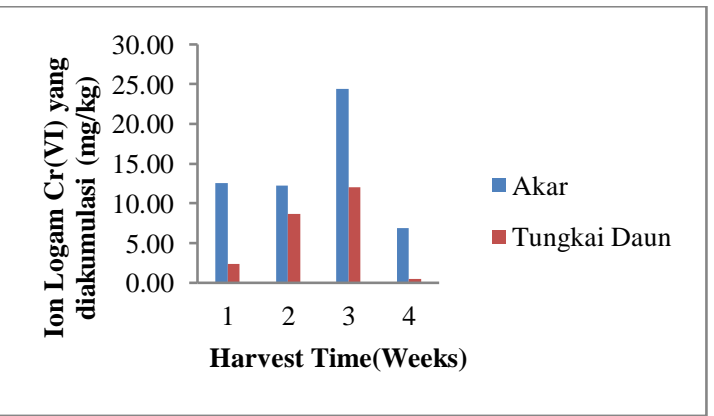

Figure 3. Distribution of $[\mathrm{Cr}]$ in the roots and in the leaves vs. Harvest time

The results of this study indicate that in general of the accumulation got the highest $\mathrm{Cr}(\mathrm{VI})$ ions is obtained at the root with the average accumulation of $\mathrm{Cr}$ (VI) ions as much as $12.51 ; 12,24 ; 24,38$; and 
$6.87 \mathrm{mg} / \mathrm{kg}$ (especially the third week as much as $24.38 \mathrm{mg} / \mathrm{kg}$ ) then in the leaves with an average accumulation of 2.33; $8.70 ; 12.00$; and $0.49 \mathrm{mg} / \mathrm{kg}$ (Figure 3). The same was found by Muliadi (2013) who used Ipomea reptana and Hartanti et al. (2014) who used water hyacinth plants to accumulate $\mathrm{Cr}(\mathrm{VI})$ ions.

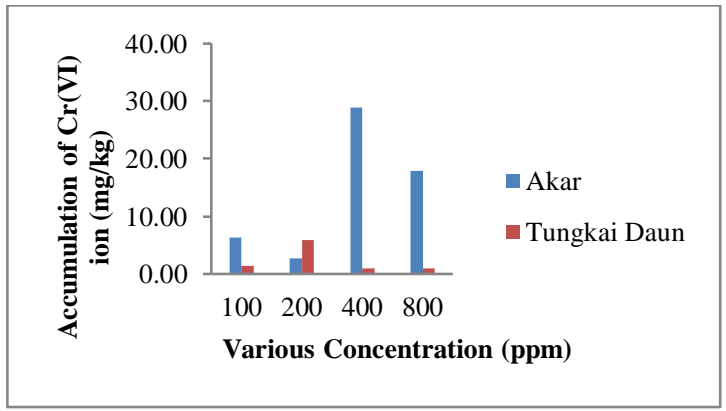

Figure 4. Distibution of $\mathrm{Cr}(\mathrm{VI})$ in the roots and leaves vs. Variation of $[\mathrm{Cr}]$ on growing media

The results obtained showed that the Cr (VI) ion accumulated the highest in successive roots $6.39 ; 2.69 ; 28,92$; and $17.87 \mathrm{mg} / \mathrm{kg}$ then leaf limbs respectively 1.46; 5.85; 0.97; and $0.98 \mathrm{mg} / \mathrm{kg}$ (Figure 4). However, at pollutant concentration of 200ppm, Cr (VI) metal ions accumulated the most in the leaves $(5.85 \mathrm{mg} / \mathrm{kg})$ than in the roots $(2.69 \mathrm{mg} / \mathrm{kg})$. This is because the metal ion $\mathrm{Cr}$ (VI) absorbed in the roots undergoes translocation from the root to the limbs through the transport network of the plant. The difference in metal uptake in plants is caused by the number and surface area of the roots, the height and width of the leaves and the large number of leaves owned by the Snake plant.

According to Lasat (2000), the high accumulation in roots occurs because metals can be complexed and stored in vacuole cell organelles so that it is difficult to translocate to the top of plants.

\section{CONCLUSION}

The conclusions obtained from the results of this study are as follows.

1. The Snake plant has no potential as hyperaccumulator plant for $\mathrm{Cr}$ (VI) because it is only able to = accumulate metal ions Cr (VI) below 1000 ppm.

2. The accumulation of $\mathrm{Cr}(\mathrm{VI})$ metal ions in the Snake plant was the largest in the third week, which was $6.30 \mathrm{mg} / \mathrm{kg}$.

3 . The type of phytoremediation mechanism that occurs in the accumulation of $\mathrm{Cr}$ (VI) metal ions in the Snake plant is rhizofiltration.

\section{REFRENCES}

Aiyen, 2004, Importance of Root Growth Parameters to $\mathrm{Cd}$ and $\mathrm{Zn}$ Acquisition by Nonhyperaccumulator and hyperaccumulator Plants, Disseraion University of Hohenhein, Institutebof Plants Nutrition, Verlag Graner- MeurenStutgard.

ASTDR, 2006, Case Studies In Environmental Medicine. Chromium Toxicity, U.S. Departement of Health and Human Services.

Candra, P., Khoirina, D.W., Firdaus, and Maulidin, 2007, Utilization of Heavy Metal Liquid Waste in the Textile Industry for Iron Metal Coating with Electroplating Method, LPPM, Yogyakarta..

Cave, R.L., Butler, O., Chenery, S.R.N., Cook, J.M., Cresser, M.S., dan Miles, D.L., 2000, Atomic Spectrometry Update Enviremental Analysis, J. Anal. At.

Spectrom, 16: 194-235.

Fardiaz, S., 2008, Polusi Air dan Udara, Kanisius, Yogyakarta.

Gosh, M., and Singh, S.P. 2005. Comparative Intake and Phytpextraction Study of Soil 
Induced Chromium by Accumulation and High Biomas Sweed Spesies, Applied Ecology and Enviromental Research, 3(2): 67-69.

Hardiani, H., 2009, Potential of Plants in Accumulating $\mathrm{Cu}$ Metal in Soil Media Accumulated by Solid Paper Industry, Phytochemical Journal, 44 (1): 27-40.

Hartanti, P.I., Haji, A.T.S., Wirosoedarmo, R., 2014, Effect of Dichengia (Eichornia crassipes) Plant Density on Chromium Metal Decrease in Liquid Tannery Liquid, Journal of Natural Resources and Environment, 1: 31-37.

Jeliazko, V.D., 2001, Study on Heavy Metals Absorption by Plants, University of Massachusetts Amherst.

Liong, S., Noor, A., Taba, P., Abdullah, A., 2010, Study of Phytoaccumulation of $\mathrm{Pb}$ in Land Kale (Ipomea reptans Poir), (Online), (http://www.pustaka.ut.ac .id), accessed on the 20th of November 2015 at 17.00 WITA.

Mimaki, Y., Inoue, T., Sashida, Y., 1996, Steroidal Saponins From Sansevieria trifasciata, Elsevier Science Ltd., 43(6): 1325-1331.

Muliadi, Liestianty, D., and Yanny, 2013, Phytoremediation: Accumulation and Distribution of Heavy Metal Cadmium Nickel and Chromium in Ipomea reptana Plants, Phytoremediation, 1: 1-5.

Nouairi, I., Ammar, W.B., Youssef, N.B., Daoud, D.B.M., Ghorbal, MH., dan Zarrouk, M., 2006, Compaarative Study of Cadmium Efffects on Membrane Lipid Composition of Brassica juncea and Brassica napus leaves, Plant Science, 170(3): 511519.

Piotrowska-Cyplik, A., dan Czarnecki, Z., 2005, Phytoextraction of $\mathrm{Pb}, \mathrm{Cr}$, and Cd by Hemp During Sugar Industry
Anaerobic Sewage, Sludge

Treatment, Electronic Journal of Polish Agricultural Universites, 8(1): 1-7.

Pradipta, A., 2011, Effect of Extraction Method on the Antibacterial Activity of Ethanol Extract of Sansiveria Leaf Trifasiata Prain Against Staphlococcus aureus IFO 13276 and Pseudomonas aeruginosa IFO 12698, Faculty of Technology, University of Atma Jaya, Yogyakarta.

Purwanto, A.W., 2006, Sansevieria: Beautiful Poisonous Absorbent Flora, Kanisius, Yogyakarta.

Putri, Y.D., Holik, H.B., Musfiroh, I., 2014, Utilization of Ponterideceae as a Phytoremediation Agent in the Processing of Chrome Waste in the Leather Tanning Industry, IJPST, 1 (1): 26-33.

Subroto, M.A, 1996, Phytoremediation. In: Proceedings of the Training and Workshop on the Role of Bioremediation in Environmental Management, Cibinong, 24-25 June 1996.

Yoon, J., Cao, X., Zhou, Q., dan Ma, L.Q., 2006, Accumulation of $\mathrm{Pb}, \mathrm{Cu}$, and $\mathrm{Zn}$ in Native Plants Growing on A Contamined Florida Site, Science of The Total Envirement, 368(2): 456464.

Yusuf, M., Zubair, A., and Arsyad, A., 2015, Phytoremediation of SoilPolluted $\mathrm{Pb}$ and $\mathrm{Cd}$ Soil Using Using Tongue Mert Plants (Sansevieria trifasciata), unpublished thesis, Hasanuddin University. 